\title{
Молекулярная эволюция белков, содержащих домен фосфолипазы A2, у плоских червей
}

\author{
Бочарникова М.Е., 2*, Афонников Д.А., ${ }^{1,2}$ \\ ${ }^{1}$ Институт ичитологии и генетики СО РАН, Новосибирск, Россия \\ ${ }^{2}$ Новосибирский государственный университет, Новосибирск, Россия \\ *m.bocharnikova@g.nsu.ru
}

Ключевые слова: PLA2, фосфолипаза A2, домены, плоские черви, молекулярная эволюция

Мотиваџия и цุель: Фосфолипазы - группа ферментов (класс гидролазы), которые катализируют процесс гидролиза фосфолипидов [1]. В работе рассмотрены фосфолипазы А2, которые отщепляют $\mathrm{SN}-1$ и $\mathrm{SN}-2$ ацильную цепь. Они известны тем, что являются токсинами яда у змей. В отличие от змеиных фосфолипаз, у плоских червей гомологи PLA2 изучены слабо; предполагается, что у паразитических плоских червей они разрушают мембраны хозяина для упрощения получения питательных веществ. По предварительным данным, у гомологов PLA2 плоских червей (свободноживущих и паразитических) варьирует доменный состав. Паразитические черви представляют угрозу здоровью населения в Сибири. Заболевания, вызванные ими, могут вызывать осложнения (желчекаменную болезнь или рак) [2]. В этой связи фосфолипазы представляют интерес для изучения, поскольку могут участвовать в процессе взаимодействий паразит-хозяин. Целью работы является изучение особенностей структуры, функций и эволюции белков, содержащих фосфолипазный домен А2 у плоских червей.

Meтоды и алгоритмы: Биоинформатический анализ данных включал следующие этапы: выбор последовательностей фосфолипаз А2 позвоночных для поиска их ортологов у плоских червей; выбор геномов плоских червей и моллюсков (в качестве внешней группы для филогенетического анализа); для выделения ортологических групп была использована программа Orthofinder [3]; для фосфолипаз группы 3 проведен дополнительный филогенетический анализ; аннотация функции белковых последовательностей осуществлялась на основе отношений ортологии.

Pезультаты: Предложен биоинформатический метод выявления белков семейства фосфолипаз А2 у плоских червей. У плоских червей впервые выявлены классы фосфолипаз А2 11 семейств, которые имеют общих предков с генами моллюсков. Фосфолипазы группы 3 среди паразитических плоских червей представлены только у трематод, включают $\mathrm{N}$-терминальный домен с неизвестной функцией и разделяются на две группы по наличию мотива $\mathrm{WxGxG}$ в активном центре белка.

\section{Список литературь}

1. Кнорре Д.Г., Мызина С.Д. Биологическая химия. М.: Высш. шк., 1998.

2. Пахарукова М.Ю. Структурно-функциональная организация системы метаболизма ксенобиотиков у возбудителя описторхоза Opisthorchis felineus (Rivolta, 1884): Дис. Новосибирск: Гос. науч. центр вирусологии и биотехнологии «Вектор», 2016.

3. Emms D.M., Kelly S. OrthoFinder: solving fundamental biases in whole genome comparisons dramatically improves orthogroup inference accuracy. Genome Biology. 2015;16(1):1-14. 